\section{Occurrence of green tobacco sickness and associated factors in farmers residing in Dom Feliciano Municipality, Rio Grande do Sul State, Southern Region of Brazil}

\author{
Ocorrência da doença da folha verde do tabaco \\ e fatores associados entre fumicultores no \\ Município de Dom Feliciano, Rio Grande do Sul, \\ Região Sul do Brasil
}

\author{
Ocurrencia de la enfermedad del tabaco verde y \\ factores asociados en agricultores que residen \\ en el Municipio de Dom Feliciano, Estado de \\ Rio Grande do Sul, Región Sur de Brasil
}

Élida Campos 1

Vanessa Indio-do-Brasil da Costa 1

Sérgio Rabello Alves 2

Ana Cristina Simões Rosa 2

Bárbara Rodrigues Geraldino 1

Beatriz da Cruz Meira 3

Valéria Cunha 1

Tânia Maria Cavalcante 4

Silvana Rubano Turci 2

Marcia Sarpa 1

Ubirani Barros Otero 1

doi: 10.1590/0102-311X00122719

\begin{abstract}
This study aimed to evaluate the occurrence of the green tobacco sickness (GTS) and its associated factors in tobacco familiar farmers residing in Dom Feliciano, Rio Grande do Sul State, Brazil. A cross-sectional study was conducted evaluating the sickness in 354 small tobacco farmers, between October 2011 and March 2012. The urinary concentration of cotinine, a biomarker of exposure to nicotine, was determined during the tobacco harvest period. Subjects presenting cotinine urinary levels $\geq 50 \mathrm{ng} / \mathrm{mL}$, that had contact with tobacco leaves up to 48 hours before the sample collection and reported at least one disease symptom were deemed as cases. A non-conditional logistic analysis was performed to evaluate the association between GTS and the population characteristics. A total of 122 (34.5\%) cases were identified, with 39\% of them being smokers and $61 \%$ being males. The median cotinine urinary concentrations were $75.6 \mathrm{ng} / \mathrm{mL}(74.1 \mathrm{ng} / \mathrm{mg}$ of creatinine) for non-cases and $755.8 \mathrm{ng} /$ $m L$ (632.1ng/mg of creatinine) for the cases ( $p$-value $\leq 0.01)$. The multivariate analysis showed a positive association between GTS and sunlight exposure time, exposure to pesticides, worse health status, and inverse association with wood cultivation. This study presented a high GTS prevalence and suggest that the use of urinary cotinine is a significant biomarker to determine GTS cases, influencing in the distribution by sex. Once the tobacco production involves health hazards, is important to implement measures to prevent the harm caused to tobacco farmers, as set in articles 17 and 18 of the World Health Organization Framework Convention on Tobacco Control.
\end{abstract}

Correspondence

E. Campos

Área Técnica Ambiente, Trabalho e Câncer, Coordenação de Prevenção e Vigilância, Instituto Nacional de Câncer José Alencar Gomes da Silva.

Rua Marquês do Pombal 125, 5o andar, Rio de Janeiro, RI 20230-240, Brasil.

elidacamp@gmail.com

${ }_{1}^{1}$ Coordenação de Prevenção e Vigilância, Instituto Nacional de Câncer José Alencar Gomes da Silva, Rio de Janeiro, Brasil. 2 Escola Nacional de Saúde Pública Sergio Arouca, Fundação Oswaldo Cruz, Rio de Janeiro, Brasil.

3 Secretaria da Saúde do Estado do Rio Grande do Sul, Porto Alegre, Brasil.

4 Secretaria Executiva, Instituto Nacional de Câncer José

Alencar Gomes da Silva, Rio de Janeiro, Brasil. 


\section{Introduction}

The exposure to large quantities of nicotine coming from tobacco farming may cause the green tobacco sickness (GTS), a condition characterized by an acute toxicity caused by the dermal absorption of nicotine 1 . The GTS occurs due to a stimulation or inhibition of receptors in the central nervous system 2 , resulting in headache, dizziness, nausea, vomiting, weakness, and abdominal pain 1,2. The GTS symptoms can be easily confused with ones of other causes, such as toxicity by pesticides 3 . Thus, for a GTS diagnosis, it is necessary that the subject had contact with a green tobacco leaf and presented high nicotine levels in the body 1.

The GTS is a significant cause of sickness among rural workers that cultivate tobacco 4 . Epidemiological studies conducted with tobacco-farming workers in different countries (such as Thailand, India, and the United States) have shown different GTS prevalence, ranging from $8 \%$ to $47 \% 5,6,7$. In Brazil, a study performed in São Lourenço do Sul, Rio Grande Sul State, reported a GTS prevalence of $7 \%$ in males and $12 \%$ in females 8 .

The occurrence of GTS presents a special significance in the national scenario, as Brazil is the main exporter and the second larger producer of tobacco in the world 9 . In such context, the Southern region is responsible for most of the tobacco culture in Brazil, concentrating more than $90 \%$ of the production 10 . Thus, considering the importance of tobacco culture in the country, understanding the features of the farmer populations that cultivate tobacco and are associated to this disease is pivotal to implement strategies for preventing and mitigating possible hazards. In such context, it is stressed that the Brazilian government ratified the first public health treaty in the world in 2005: the World Health Organization Framework Convention on Tobacco Control (WHO-FCTC), already in effect in 181 countries. The WHO-FCTC aims to "protect the present and future generations against the devastating sanitary, social, environmental, and economic consequences generated by the consumption and exposure to tobacco smoke" and, in its 38 articles, it recommends that measures related to reduction in demand (Part III) and reduction in tobacco offer (Part IV) are adopted. Articles 17 and 18 are highlighted, proposing the adoption of measures to support economically feasible alternate activities and recommending the protection of the environment and the health of persons involved in tobacco planting, respectively 11. Therefore, in consonance with the WHO-FCTC objectives, this study aims to evaluate the occurrence of GTS and the associated factors in tobacco-producing farmers residing in Dom Feliciano, Rio Grande do Sul State, the thirteenth largest tobacco-producing municipality in the country 12 .

\section{Methodology}

\section{Study population}

This study was conducted from the research entitled Health and Sustainable Development in the Familiar Agriculture in Tobacco-Producing Regions, whose objective was to evaluate the health profile in the population residing in Dom Feliciano Municipality and the main risk factors for cancer. Tobaccoproducing familiar farmers, residing in Dom Feliciano Municipality, from both sexes, adults (over 18 years old), able to understand and answer to the questionnaires, and speaking Portuguese were selected from such populational inquiry for the present study.

Dom Feliciano has a total of 2,252 tobacco farmers 9, and 354 among them were selected to take part in the survey. Such sample size was calculated considering the prevalence of 0.184 for toxicity by the nicotine present in tobacco leaves 3 , with an admissible error of 0.05 and confidence level of 0.95 , resulting in a minimum size of 210 subjects.

\section{Data collection}

The interviews were structured as medical history and were performed by trained health agents and local supervisors of the team of the Municipal Health Secretariat of Dom Feliciano Municipality. The participants were questioned in two steps: (1) tobacco crop planting, aiming to identify toxicity conditions by pesticides; and (2) tobacco harvest, which is suggested as being the time when 
there is the largest exposure to nicotine by requiring larger contact with tobacco leaves. The first step was performed between August and October 2011 and the second step between January and February 2012.

An individual questionnaire and a clinical questionnaire were applied to obtain general information and information on acute toxicity and exposure to pesticides, respectively. Both questionnaires were applied on the first step, and only the clinical questionnaire was applied on the second step. However, in this study, we only use the data from the clinical questionnaire of the second step, as the tobacco harvest step offers larges exposure of the worker to nicotine and smaller contact with pesticides, which toxicity conditions present similarities. In order to determine the food insecurity condition, the Brazilian Scale of Food Insecurity ${ }^{13}$ was included in the general information questionnaire. In this study, the variable food insecurity was treated as being dichotomous, with a score equal to zero being classified as food safety and a scorer higher than or equal to one being classified as food insecurity. Alcoholism was determined from the four questions that compose the CAGE questionnaire 14 , also included in the general evaluation.

Subjects presenting quantifiable cotinine urinary levels $(\geq 50 \mathrm{ng} / \mathrm{mL})$, in contact with tobacco leaves in up to 48 hours before the sample collection, and that reported at least one disease symptom (headache, dizziness, nausea, vomiting, weakness, and bellyache) were considered as being GTS cases. The other variables evaluated in this study are described in Tables 1 and 2.

Table 1

Features of the study population. Dom Feliciano Municipality, Rio Grande do Sul State, Brazil ( $N=354)$.

\begin{tabular}{|c|c|c|c|}
\hline & $\begin{array}{l}\text { Total } \\
\text { n (\%) }\end{array}$ & $\begin{array}{c}\text { Non-cases } \\
\text { n (\%) }\end{array}$ & $\begin{array}{c}\text { Cases * } \\
\text { n (\%) }\end{array}$ \\
\hline \multicolumn{4}{|l|}{ Demographic variables } \\
\hline \multicolumn{4}{|l|}{ Sex } \\
\hline Male & $200(56.5)$ & $126(54.3)$ & $74(60.7)$ \\
\hline Female & $154(43.5)$ & $106(45.7)$ & 48 (39.3) \\
\hline \multicolumn{4}{|l|}{ Age at evaluation (years) } \\
\hline$\leq 25$ & $53(15.1)$ & 31 (13.4) & $22(18.2)$ \\
\hline $26|-| 35$ & $81(23.0)$ & $48(20.8)$ & $33(27.3)$ \\
\hline $36|-| 45$ & $105(29.8)$ & $71(30.7)$ & $34(28.1)$ \\
\hline $46|-| 55$ & $61(17.3)$ & $37(16.0)$ & $24(19.8)$ \\
\hline $56|-| 65$ & $31(8.8)$ & $25(10.8)$ & $6(5.0)$ \\
\hline$>65$ & $21(6.0)$ & $19(8.2)$ & $2(1.7)$ \\
\hline \multicolumn{4}{|l|}{ Skin color } \\
\hline Non-white & $58(16.4)$ & $35(15.1)$ & $23(19.0)$ \\
\hline White & $295(83.6)$ & $197(84.9)$ & $98(81.0)$ \\
\hline \multicolumn{4}{|l|}{ Socioeconomic variables } \\
\hline \multicolumn{4}{|l|}{ Educational level } \\
\hline High school or higher education & $42(12.5)$ & $25(11.4)$ & $17(14.7)$ \\
\hline Up to elementary school & $293(87.5)$ & $194(88.6)$ & $99(85.3)$ \\
\hline \multicolumn{4}{|l|}{ Food security } \\
\hline Yes & $271(78.8)$ & $184(81.4)$ & $87(73.7)$ \\
\hline No & $73(21.2)$ & $42(18.6)$ & $31(26.3)$ \\
\hline
\end{tabular}

(continues) 
Table 1 (continued)

\begin{tabular}{|c|c|c|c|}
\hline & $\begin{array}{l}\text { Total } \\
\text { n (\%) }\end{array}$ & $\begin{array}{c}\text { Non-cases } \\
\text { n (\%) }\end{array}$ & $\begin{array}{c}\text { Cases * } \\
\text { n (\%) }\end{array}$ \\
\hline \multicolumn{4}{|l|}{ Health condition variables } \\
\hline \multicolumn{4}{|l|}{ Health status } \\
\hline Good or very good & $147(41.5)$ & $104(44.8)$ & $43(35.2)$ \\
\hline Regular & $175(49.4)$ & $106(45.7)$ & $69(56.6)$ \\
\hline Poor or very poor & $32(9.0)$ & $22(9.5)$ & $10(8.2)$ \\
\hline \multicolumn{4}{|l|}{ Smoking } \\
\hline Never smoked & $122(34.5)$ & $81(34.9)$ & $41(33.6)$ \\
\hline Ex-smoker & $48(13.6)$ & $39(16.8)$ & $9(7.4)$ \\
\hline Passive smoker & $67(18.9)$ & $42(18.1)$ & $25(20.5)$ \\
\hline Active smoker & $117(33.1)$ & $70(30.2)$ & $47(38.5)$ \\
\hline \multicolumn{4}{|l|}{ Age when began to smoke (years) } \\
\hline$>15$ & $85(54.1)$ & $53(52.5)$ & $32(57.1)$ \\
\hline$\leq 15$ & $72(45.9)$ & $48(47.5)$ & $24(42.9)$ \\
\hline \multicolumn{4}{|l|}{ Abusive use of alcohol } \\
\hline No & 199 (79.9) & $94(86.2)$ & $50(78.1)$ \\
\hline Yes & $50(20.1)$ & $15(13.8)$ & 14 (21.9) \\
\hline \multicolumn{4}{|c|}{ Age when began to consume alcohol (years old) } \\
\hline$>15$ & $161(59.9)$ & $106(59.6)$ & $55(60.4)$ \\
\hline$\leq 15$ & $108(40.1)$ & $72(40.4)$ & $36(39.6)$ \\
\hline \multicolumn{4}{|l|}{ BMI } \\
\hline Light or normal weight $\left(\leq 24.9 \mathrm{~kg} / \mathrm{m}^{2}\right)$ & $174(50.1)$ & $118(53.9)$ & $65(58.6)$ \\
\hline Overweight (from 25.0 to $29.9 \mathrm{~kg} / \mathrm{m}^{2}$ ) & $118(34.0)$ & $74(33.8)$ & $32(28.8)$ \\
\hline Obesity $\left(\geq 30.0 \mathrm{~kg} / \mathrm{m}^{2}\right)$ & $55(15.9)$ & $27(12.3)$ & $14(12.6)$ \\
\hline \multicolumn{4}{|l|}{ Sunlight exposure (times/week) } \\
\hline$\leq 2$ & $7(2.0)$ & $6(2.6)$ & $1(0.8)$ \\
\hline $3-6$ & $31(8.8)$ & $21(9.1)$ & $10(8.2)$ \\
\hline Daily & $316(89.3)$ & $205(88.4)$ & $111(91.0)$ \\
\hline \multicolumn{4}{|l|}{ Time of sunlight exposure (hours) } \\
\hline$\leq 6$ & $96(27.3)$ & $77(33.3)$ & 19 (15.7) \\
\hline $7-8$ & $175(49.7)$ & $105(45.5)$ & 70 (57.9) \\
\hline$>8$ & $81(23.0)$ & $49(21.2)$ & $32(26.4)$ \\
\hline \multicolumn{4}{|l|}{ Use of sunscreen or sun protector } \\
\hline Always & $27(7.6)$ & $16(6.9)$ & $11(9.0)$ \\
\hline Sometimes & $36(10.2)$ & $24(10.3)$ & $13(10.7)$ \\
\hline No & $7(2.0)$ & $192(82.8)$ & $98(80.3)$ \\
\hline \multicolumn{4}{|l|}{ Use of hat or cap } \\
\hline Always & 311 (87.9) & $204(87.9)$ & $107(87.7)$ \\
\hline Sometimes & $36(10.2)$ & $22(9.5)$ & $14(11.5)$ \\
\hline No & $7(2.0)$ & $6(2.6)$ & $1(0.8)$ \\
\hline \multicolumn{4}{|l|}{ Use of long-sleeved shirt } \\
\hline Always & $167(47.2)$ & $107(46.1)$ & $60(49.2)$ \\
\hline Sometimes & $101(28.5)$ & $69(29.7)$ & $32(26.2)$ \\
\hline No & $86(24.3)$ & $56(24.1)$ & $30(24.6)$ \\
\hline \multicolumn{4}{|l|}{ Use of long pants } \\
\hline Always & $192(54.2)$ & $127(54.7)$ & 65 (53.3) \\
\hline Sometimes & 106 (29.9) & $69(29.7)$ & $37(30.3)$ \\
\hline No & $56(15.8)$ & $36(15.5)$ & $20(16.4)$ \\
\hline
\end{tabular}

BMI: body mass index.

* Comparison between cases and non-cases: chi-square or Fisher test (bold: p-value $\leq 0.05$ ). 
Table 2

Agricultural practice of the study population. Dom Feliciano Municipality, Rio Grande do Sul State, Brazil (N = 354).

\begin{tabular}{|c|c|c|c|}
\hline & $\begin{array}{l}\text { Total } \\
\text { n (\%) }\end{array}$ & $\begin{array}{c}\text { Non-cases } \\
\text { n (\%) }\end{array}$ & $\begin{array}{c}\text { Cases * } \\
\text { n (\%) }\end{array}$ \\
\hline \multicolumn{4}{|c|}{ Time of work with tobacco crop (years) } \\
\hline$\leq 10$ & $82(23.3)$ & $54(23.5)$ & $28(23.0)$ \\
\hline$>10$ & $270(76.7)$ & $176(76.5)$ & $94(77.0)$ \\
\hline \multicolumn{4}{|l|}{ Manual cleansing } \\
\hline No & $70(20.1)$ & $41(18.1)$ & $29(24.0)$ \\
\hline Yes & 278 (79.9) & $186(81.9)$ & $92(76.0)$ \\
\hline \multicolumn{4}{|l|}{ Chemical cleansing } \\
\hline No & $233(67.0)$ & $150(66.1)$ & $83(68.6)$ \\
\hline Yes & $115(33.0)$ & 77 (33.9) & $38(31.4)$ \\
\hline \multicolumn{4}{|l|}{ Mechanical cleansing } \\
\hline No & $214(61.5)$ & $143(63.0)$ & $71(58.7)$ \\
\hline Yes & $134(38.5)$ & $84(37.0)$ & $50(41.3)$ \\
\hline \multicolumn{4}{|l|}{ Uses manual stove } \\
\hline No & $44(12.5)$ & $28(12.2)$ & $16(13.1)$ \\
\hline Yes & $308(87.5)$ & $202(87.8)$ & $106(86.9)$ \\
\hline \multicolumn{4}{|l|}{ Uses electric stove } \\
\hline No & 259 (73.6) & $175(76.1)$ & $84(68.9)$ \\
\hline Yes & $93(26.4)$ & 55 (23.9) & $38(31.1)$ \\
\hline \multicolumn{4}{|c|}{ Uses manual and electric stove } \\
\hline No & $303(86.1)$ & $203(88.3)$ & $100(82.0)$ \\
\hline Yes & $49(13.9)$ & $27(11.7)$ & $22(18.0)$ \\
\hline \multicolumn{4}{|c|}{ Skin injuries at the tobacco harvest } \\
\hline No & $295(90.8)$ & $183(90.1)$ & $112(91.8)$ \\
\hline Yes & $30(9.2)$ & $20(9.9)$ & $10(8.2)$ \\
\hline \multicolumn{4}{|c|}{ Tobacco harvest with humid/wet clothes } \\
\hline No & $128(36.6)$ & $87(38.2)$ & $41(33.6)$ \\
\hline Yes & $222(63.4)$ & $141(61.8)$ & $81(66.4)$ \\
\hline \multicolumn{4}{|c|}{ Time of harvest of tobacco leaves } \\
\hline Morning or afternoon & $13(3.7)$ & $9(4.0)$ & $4(3.3)$ \\
\hline Morning and afternoon & $335(96.3)$ & $217(96.0)$ & $118(96.7)$ \\
\hline \multicolumn{4}{|c|}{ Use of full PPE when working with tobacco ** } \\
\hline Yes & $45(12.7)$ & $29(12.6)$ & $16(13.1)$ \\
\hline No & $308(87.3)$ & $202(87.4)$ & $106(86.9)$ \\
\hline \multicolumn{4}{|c|}{ Got sick in up to 3 days after the tobacco harvest } \\
\hline No & $235(67.0)$ & $161(70.3)$ & $74(60.7)$ \\
\hline Yes & $116(33.0)$ & $68(29.7)$ & $48(39.3)$ \\
\hline \multicolumn{4}{|l|}{ Bean cultivation } \\
\hline No & $38(10.7)$ & $31(13.4)$ & $7(5.4)$ \\
\hline Yes & $316(89.3)$ & $201(86.6)$ & $115(94.3)$ \\
\hline \multicolumn{4}{|l|}{ Corn cultivation } \\
\hline No & $19(5.4)$ & $12(5.2)$ & $7(5.7)$ \\
\hline Yes & $335(94.6)$ & $220(94.8)$ & $115(94.3)$ \\
\hline \multicolumn{4}{|c|}{ Cultivation of vegetables, fruits, and legumes } \\
\hline No & $30(8.5)$ & $23(9.9)$ & $7(5.8)$ \\
\hline Yes & $323(91.5)$ & $209(90.1)$ & 114 (94.2) \\
\hline
\end{tabular}

(continues) 
Table 2 (continued)

\begin{tabular}{|c|c|c|c|}
\hline & $\begin{array}{l}\text { Total } \\
\text { n (\%) }\end{array}$ & $\begin{array}{c}\text { Non-cases } \\
\text { n (\%) }\end{array}$ & $\begin{array}{c}\text { Cases * } \\
\text { n (\%) }\end{array}$ \\
\hline \multicolumn{4}{|c|}{ Wood cultivation } \\
\hline No & $175(49.6)$ & $106(45.9)$ & $69(56.6)$ \\
\hline Yes & $178(50.4)$ & $125(54.1)$ & $53(43.4)$ \\
\hline \multicolumn{4}{|c|}{ Rice cultivation } \\
\hline No & $343(98.0)$ & $225(98.3)$ & $118(97.5)$ \\
\hline Yes & $7(2.0)$ & $4(1.7)$ & $3(2.5)$ \\
\hline \multicolumn{4}{|c|}{ Exposure to pesticides } \\
\hline No & $45(12.7)$ & $29(12.5)$ & $16(13.1)$ \\
\hline Yes & $309(87.3)$ & $203(87.5)$ & $106(86.9)$ \\
\hline \multicolumn{4}{|c|}{$\begin{array}{l}\text { Age when the contact with pesticides began } \\
\text { (years) }\end{array}$} \\
\hline$>15$ & $212(70.4)$ & $144(73.5)$ & $68(64.8)$ \\
\hline$\leq 15$ & $89(29.6)$ & $52(26.5)$ & $37(35.2)$ \\
\hline \multicolumn{4}{|c|}{ Got sick after applying/working with pesticides } \\
\hline No & $208(69.8)$ & $140(72.2)$ & $68(65.4)$ \\
\hline Yes & $90(30.2)$ & $54(27.8)$ & $36(34.6)$ \\
\hline \multicolumn{4}{|c|}{ Use of full PPE when applying pesticides *** } \\
\hline No & $246(85.4)$ & $165(86.4)$ & $81(83.5)$ \\
\hline Yes & $42(14.6)$ & 26 (13.6) & 16 (16.5) \\
\hline
\end{tabular}

PPE: personal protective equipment.

* Comparison between cases and non-cases: chi-square or Fisher test (bold: $p$-value $\leq 0.05$ );

** Joint wear of gloves, overall, or long-sleeved shirt and pants, boots, and coat;

*** Joint wear of gloves, overall, or long-sleeved shirt and pants, boots, and mask.

\section{Biological analysis}

\section{- Standards, reagents, and quality policy}

Negative calibrator, 0ng/mL (6626493/2012-05); negative control, 50ng/mL (6623399/2012-11); cutoff calibrator, 500ng/mL (6623400/2012-11), positive control, 5,000ng/mL (6623401/2012-11); plate (6625998/2012-08); enzyme conjugate (662497/2012-08); substrate reagent (6614535/201302); stopping reagent (6625819/2013-05). All supplies for the enzyme immunoassay (EIA) were purchased from OraSure Technologies, Inc. (Bethlehem, USA) using a kit (662498/2012-05).

The colorimetric creatine kit, model K016 with standard, alkaline, and acid reagents and picric acid (0158/2013-11) were purchased from Bioclin Ltda. (Belo Horizonte, Brazil). Due to a laboratory quality policy (accreditation by the Joint International Commission in 2012) and to the initial start procedures for adopting the ABNT NBR ISO/IEC 17025:(2005), all precision instruments (e.g., glassware, automatic pipettes, spectrophotometer, etc.) were previously calibrated and certified.

\section{- Used instruments}

Microplate reader able to read at dual wavelength of 450nm and 630nm, model Asys - Expert Plus, purchased from Biochrom Ltd. (London, UK); microplate washer, model Stat Fax - 2600, purchased from Awareness Technology, Inc. (Palm City, USA); UV-Visible spectrophotometer, model UV-1601, purchased from Shimadzu Co (Kyoto, Japan). 


\section{- Analytical method principle and procedure to determine cotinine urinary levels}

The EIA for cotinine is a competitive microplate immunoassay for qualitative and semiquantitative determination of such compound in urine samples. Reagents and samples were brought to room temperature $\left(20^{\circ} \mathrm{C} \pm 2^{\circ} \mathrm{C}\right)$ before the analysis. Ten microliters of sample, calibrator, or control were added to each well test and properly labeled. One hundred microliters of enzyme conjugate were transferred to each testing well of the plate, and incubation was performed for 30 minutes at room temperature $\left(20^{\circ} \mathrm{C} \pm 2^{\circ} \mathrm{C}\right)$ in the dark. Each well was washed six times with 300 microliters of distilled water by using a suitable plate washer. One hundred microliters of substrate reagent were added to each well and were incubated at room temperature for 30 minutes in the dark $\left(20^{\circ} \mathrm{C} \pm 2^{\circ} \mathrm{C}\right)$. One hundred microliters of stopping reagent were transferred to each well. The absorbance was measured at a dual wavelength of $450 \mathrm{~nm}$ and $630 \mathrm{~nm}$ within 30 minutes since the reaction was stopped. For the quantification procedure, curve calibrators with different cotinine concentrations ( $\mathrm{n}=3$, in duplicate) were prepared by plotting the negative absorbance values of raw absorbance data of cotinine observed in negative, low, medium and high calibrators against such metabolite analyte concentrations. The positive absorbance values of samples in such standard curve and the final concentrations were compared. The assay sensitivity was $50 \mathrm{ng} / \mathrm{mL}$ for quantification (LOQ). No specificity was found in crossreactivity to 16 compounds of toxicological interest at $10,000 \mathrm{ng} / \mathrm{mL}$ in preserved human urine 15 .

\section{- Assay to determine creatinine urinary level}

Creatinine was measured in urine (250 microliters of sample volume) by final point colorimetry (modified Jaffe method) 16 .

\section{Statistical analysis}

The descriptive analysis of the features of the study population was performed by frequency distribution and univariate analysis of categorical variables by using the chi-square test. Central trend and dispersion measurements were calculated for continuous variables. The normality of the continuous variables was evaluated by using the Kolmogorov-Smirnov test. Bivariate analyses stratified by gender and smoking were performed, using the non-parametric group comparison Mann-Whitney, Fisher tests, or chi-square, with Bonferroni post-hoc test. Cotinine levels under the quantification limit were considered as being zero.

Bivariate and multivariate non-conditional logistic regression analyses were performed to evaluate the associate factors (independent variables) and GTS occurrence (dependent variable). The associate variables were included in the multivariate model with the outcome in the bivariate analyses and a statistical significance level of $\mathrm{p}$-value $\leq 0.20$. According to a forward procedure, variables associated to the dependent variable at a significance level $\leq 0.05$ were kept in the final model. The statistical analyses of the collected data were performed using the software SPSS for Windows version 17.0 (https://www.ibm.com/).

This study was approved by the Ethics Research Committe of the José Alencar Gomes da Silva National Cancer Institute (n. 120/09) and all subjects that accepted to participate in the survey signed the Free Informed Consent Term.

\section{Results}

The study population was composed by 354 subjects, which $57 \%$ being males, $84 \%$ having declared to be white, and $68 \%$ being up to 45 years old (median $=39$ years old; range $=18-87$ years old). Among the participants who declared educational level, less than $15 \%$ studied in high school or had higher education, $21 \%$ did not have food safety, half of the population declared its health status as regular and was identified as overweight or obese. Active smoking was reported by $33 \%$ of the population, and 20\% presented abusive alcohol consumption. Most population reported daily sunlight exposure of seven or more hours of exposure daily. However, continuous use of sunscreen was reported by 
only $8 \%$ of the farmers. The frequencies of regular wear of others protection forms, such as hat or cap, long-sleeved shirt, and long pants were of $88 \%, 47 \%$, and $54 \%$, respectively (Table 1).

Only two farmers produced Burley-type tobacco and more than $90 \%$ of the participants reported to perform tasks in all tobacco culture steps (seedbed preparation $=96 \%$; soil preparation $=90 \%$; tobacco planting = 97\%; tobacco crop care $=96 \%$; tobacco harvest $=98 \%$; drying of tobacco leaves $=$ $92 \%$; classification of tobacco leaves $=98 \%$; crop cleansing $=98 \%$ ). Table 2 presents the agricultural characteristics of the population. Only 13\% reported being wearing full PPE (personal protective equipment) when working. Over three quarters of the population had cultivated tobacco for over ten years. The cleaning of the crop was done manually by the most farmers, while only between $30-40 \%$, approximately, used chemical and mechanical techniques. The use of manual and electric stove was reported by $88 \%$ and $26 \%$ of the farmers, respectively. More than half of the participants wore humid clothes by the time of the harvest, which mostly occurred in the morning and afternoon times (96\%). Skin injuries by the time of the tobacco harvest were reported by $9 \%$ of the farmers and one third of them reported to having gotten sick in up to three days after the tobacco harvest. Cultivation of bean (89\%), corn (95\%), vegetables, fruits, and legumes (92\%), wood (50\%), and rice (2\%) were present besides tobacco. Referring to pesticides, $87 \%$ reported to use such chemical compounds, with $30 \%$ of them reporting having started their use as early as the age of 15 . Only $15 \%$ of the pesticide users reported to having using full PPE, and 30\% got sick after the application of such compounds.

Among the 354 participants of the study, 122 were identified as being GTS cases and, among these latter, $60.7 \%$ were males and $61.5 \%$ were non-smokers. The median cotinine urinary level in the population was $299 \mathrm{ng} / \mathrm{mg}$ of creatinine $(336 \mathrm{ng} / \mathrm{mL})$, and the GTS cases had a median concentration of $632 \mathrm{ng} / \mathrm{mg}$ of creatinine $(756 \mathrm{ng} / \mathrm{mL}$ ) (Table 3). When stratified by smoking and sex, higher cotinine levels were seen in smokers when compared to non-smokers (cases: 1,343 vs. $316 \mathrm{ng} / \mathrm{mg}$ of creatinine, $\mathrm{p}$-value $\leq 0.05$ ) and in males than in females (cases: $655 \mathrm{vs.} 609 \mathrm{ng} / \mathrm{mg}$ of creatinine, $\mathrm{p}$-value $=0.86$ ), although the difference was not statistically significant between sexes. The observed prevalence of GTS was 34.5\%. Cotinine levels above $50 \mathrm{ng} / \mathrm{mL}$ and recent contact with tobacco leaves were observed in $69 \%$ and $65 \%$ of the participants, respectively. The most frequent characteristic GTS symptom was headache (52\%), followed by dizziness (31\%), weakness (27\%), nausea (21\%), bellyache (20\%), and vomiting (10\%) (Table 4).

A difference between cases and non-cases was observed for the variables age, smoking, time of sunlight exposure, and bean cultivation (Tables 1 and 2). Higher educational level, as well as higher frequencies of former smokers, manual crop cleansing, and wood cultivation, were seen for males in the stratified bivariate analysis by sex (data not presented in a table). Furthermore, getting sick during or up to three days after the harvest presented an association to the disease among males. Referring to females, the cases were younger and presented higher time of sunlight exposure. An association between GTS and bean cultivation, skin contact with tobacco leaves, and exposure to pesticides was also seen for females. Considering smoking, both smoking and non-smoking subjects, the non-cases were older. Other GTS associated variables among non-smokers were time of sunlight exposure, bean cultivation, and exposure to pesticides. Lower educational level and higher frequency of subjects who presented abusive alcohol use were seen among the cases in smokers.

Table 5 shows the result of the final multivariate model, simultaneously adjusted for time of sunlight exposure, current exposure to pesticides, health status and wood cultivation. The analysis showed a statistically significant positive association between GTS and sunlight exposure (7-8 hours: $\mathrm{OR}=2.26$; 95\%CI: 1.16-4.40 / > 8 hours: $\mathrm{OR}=2.39$; 95\%CI: 1.14-5.03). Subjects with GTS presented a chance of exposure to pesticides almost 4 times higher (95\%CI: 1.43-9.25), as well as a chance of reporting their health status as being regular twice higher (95\%CI: 1.17-3.38), when compared to non-cases. However, a lower chance of wood cultivation was seen among the cases $(\mathrm{OR}=0.60$; $95 \% \mathrm{CI}$ : 0.37-1.00) when compared to GTS non-cases (Table 5). 
Table 3

Cotinine urinary levels in the study population. Dom Feliciano Municipality, Rio Grande do Sul State, Brazil.

\begin{tabular}{|c|c|c|c|c|c|c|c|}
\hline & $n$ * & Mean (SD) & Minimum & P25 & P50 & P75 & Maximum \\
\hline \multicolumn{8}{|l|}{ Total } \\
\hline $\mathrm{ng} / \mathrm{mL}$ & 354 & $726(954)$ & $<\mathrm{LOQ}$ & $<$ LOQ & 336 & 1,215 & 5,849 \\
\hline ng/mg of creatinine & & $961(2,337)$ & $<\mathrm{LOQ}$ & $<\mathrm{LOQ}$ & 299 & 1,114 & 31,560 \\
\hline \multicolumn{8}{|l|}{ Non-cases ** } \\
\hline Total population & 232 & & & & & & \\
\hline $\mathrm{ng} / \mathrm{mL}$ & & $533(800)$ & $<\mathrm{LOQ}$ & $<\mathrm{LOQ}$ & 76 & 1,027 & 5,375 \\
\hline $\mathrm{ng} / \mathrm{mg}$ of creatinine & & $816(2,433)$ & $<$ LOQ & $<\mathrm{LOQ}$ & 74 & 938 & 31,560 \\
\hline Males ** & 126 & & & & & & \\
\hline $\mathrm{ng} / \mathrm{mL}$ & & $685(817)$ & $<\mathrm{LOQ}$ & $<\mathrm{LOQ}$ & 417 & 1,246 & 5,375 \\
\hline $\mathrm{ng} / \mathrm{mg}$ of creatinine & & $868(1,476)$ & $<$ LOQ & $<$ LOQ & 325 & 1,133 & 9,963 \\
\hline Females & 106 & & & & & & \\
\hline $\mathrm{ng} / \mathrm{mL}$ & & $353(744)$ & $<\mathrm{LOQ}$ & $<\mathrm{LOQ}$ & $<\mathrm{LOQ}$ & 292 & 3,931 \\
\hline $\mathrm{ng} / \mathrm{mg}$ of creatinine & & $754(3,229)$ & $<\mathrm{LOQ}$ & $<\mathrm{LOQ}$ & $<\mathrm{LOQ}$ & 296 & 31,560 \\
\hline Non-smokers ** & 162 & & & & & & \\
\hline $\mathrm{ng} / \mathrm{mL}$ & & $189(435)$ & $<\mathrm{LOQ}$ & $<\mathrm{LOQ}$ & $<\mathrm{LOQ}$ & 161 & 2,619 \\
\hline $\mathrm{ng} / \mathrm{mg}$ of creatinine & & $164(345)$ & $<$ LOQ & $<\mathrm{LOQ}$ & $<\mathrm{LOQ}$ & 169 & 1,846 \\
\hline Smokers & 70 & & & & & & \\
\hline $\mathrm{ng} / \mathrm{mL}$ & & $1,330(882)$ & $<\mathrm{LOQ}$ & 809 & 1,315 & 1,747 & 5,375 \\
\hline ng/mg of creatinine & & $2,325(4,029)$ & $<$ LOQ & 710 & 1,358 & 2,399 & 31,560 \\
\hline \multicolumn{8}{|l|}{ Cases } \\
\hline Total population & 122 & & & & & & \\
\hline $\mathrm{ng} / \mathrm{mL}$ & & $1,093(1,109)$ & 50 & 279 & 756 & 1,655 & 5,849 \\
\hline $\mathrm{ng} / \mathrm{mg}$ of creatinine & & $1,236(2,125)$ & 47 & 246 & 632 & 1,345 & 19,048 \\
\hline Males ** & 74 & & & & & & \\
\hline $\mathrm{ng} / \mathrm{mL}$ & & $1,017(845)$ & 90 & 298 & 888 & 1,659 & 4,086 \\
\hline $\mathrm{ng} / \mathrm{mg}$ of creatinine & & $1,079(1,402)$ & 47 & 228 & 655 & 1,311 & 8,939 \\
\hline Females & 48 & & & & & & \\
\hline $\mathrm{ng} / \mathrm{mL}$ & & $1,211(1,425)$ & 50 & 243 & 646 & 1,618 & 5,849 \\
\hline $\mathrm{ng} / \mathrm{mg}$ of creatinine & & $1,477(2,911)$ & 64 & 282 & 609 & 1,509 & 19,048 \\
\hline Non-smokers ** & 75 & & & & & & \\
\hline $\mathrm{ng} / \mathrm{mL}$ & & 557 (509) & 50 & 175 & 420 & 771 & 2,310 \\
\hline ng/mg of creatinine & & $604(772)$ & 47 & 163 & 316 & 750 & 4,768 \\
\hline Smokers & 47 & & & & & & \\
\hline $\mathrm{ng} / \mathrm{mL}$ & & $1,949(1,264)$ & 96 & 1,180 & 1,692 & 2,021 & 5,849 \\
\hline $\mathrm{ng} / \mathrm{mg}$ of creatinine & & $2,244(3,038)$ & 171 & 731 & 1,343 & 2,645 & 19,048 \\
\hline
\end{tabular}

LOQ: quantification limit; P: percentile; SD: standard deviation.

* Percentile above the quantification limit: total population $=68.9 \%$; non-cases - total population $=52.3 \%$; males $=65.9 \%$; females $=36.8 \%$; non-smokers $=34 \%$; smokers $=95.7 \%$;

** Mann-Whitney test statistically significant ( $p$-value $\leq 0.05$ ): non-cases vs. cases (total population); males vs. females (non-cases); non-smokers vs. smokers (non-cases and cases). 
Table 4

Traits related to green tobacco sickness (GTS) in the study population. Dom Feliciano Municipality, Rio Grande do Sul State, Brazil.

\begin{tabular}{|c|c|c|c|c|c|c|c|c|c|}
\hline & \multirow{2}{*}{$\begin{array}{l}\text { Total } \\
\text { n (\%) }\end{array}$} & \multicolumn{2}{|c|}{ Males } & \multicolumn{2}{|c|}{ Females } & \multicolumn{2}{|c|}{ Non-smokers } & \multicolumn{2}{|c|}{ Smokers } \\
\hline & & $\begin{array}{c}\text { Non-cases } \\
\text { n (\%) }\end{array}$ & $\begin{array}{l}\text { Cases } \\
\text { n (\%) }\end{array}$ & $\begin{array}{c}\text { Non-cases } \\
\text { n (\%) }\end{array}$ & $\begin{array}{l}\text { Cases } \\
\text { n (\%) }\end{array}$ & $\begin{array}{c}\text { Non-cases } \\
\text { n (\%) }\end{array}$ & $\begin{array}{l}\text { Cases } \\
\text { n (\%) }\end{array}$ & $\begin{array}{c}\text { Non-cases } \\
\text { n (\%) }\end{array}$ & $\begin{array}{l}\text { Cases } \\
\mathrm{n}(\%)\end{array}$ \\
\hline \multicolumn{10}{|c|}{ Cotinine urinary levels $(\mathrm{ng} / \mathrm{mL})$} \\
\hline$\leq 50$ & $110(31.1)$ & $43(34.1)$ & - & $67(63.2)$ & - & $107(66.0)$ & - & $3(4.3)$ & - \\
\hline$>50$ & $244(68.9)$ & $83(65.9)$ & $74(100.0)$ & $39(36.8)$ & $48(100.0)$ & $55(34.0)$ & $75(100.0)$ & $67(95.7)$ & $47(100.0)$ \\
\hline \multicolumn{10}{|c|}{ Contact with tobacco leaves in the last } \\
\hline No & $123(34.7)$ & 54 (42.9) & - & $69(65.1)$ & - & $85(52.5)$ & - & $38(54.3)$ & - \\
\hline Yes & $231(65.3)$ & $72(57.1)$ & $74(100.0)$ & 37 (34.9) & $48(100.0)$ & $77(47.5)$ & $75(100.0)$ & $32(45.7)$ & $47(100.0)$ \\
\hline \multicolumn{10}{|c|}{ GTS symptoms } \\
\hline \multicolumn{10}{|c|}{ Headache } \\
\hline No & $170(48.0)$ & $91(72.2)$ & $20(27.0)$ & $51(48.1)$ & $8(16.7)$ & $94(58.0)$ & $17(22.7)$ & $48(68.6)$ & $11(23.4)$ \\
\hline Yes & $184(52.0)$ & $35(27.8)$ & $54(73.0)$ & 55 (51.9) & $40(83.3)$ & $68(42.0)$ & $58(77.3)$ & $22(31.4)$ & $36(76.6)$ \\
\hline \multicolumn{10}{|c|}{ Dizziness } \\
\hline No & 244 (68.9) & 103 (81.7) & $46(62.2)$ & $70(66.0)$ & $25(52.1)$ & $114(70.4)$ & $47(62.7)$ & $59(84.3)$ & $24(51.1)$ \\
\hline Yes & $110(31.1)$ & $23(18.3)$ & $28(37.8)$ & $36(34.0)$ & $23(47.9)$ & $48(29.6)$ & $28(37.3)$ & $11(15.7)$ & $23(48.9)$ \\
\hline \multicolumn{10}{|l|}{ Nausea } \\
\hline No & $280(79.1)$ & $116(92.1)$ & $50(67.6)$ & $80(75.5)$ & $34(70.8)$ & $132(81.5)$ & $47(62.7)$ & 64 (91.4) & 37 (78.7) \\
\hline Yes & 74 (20.9) & $10(7.9)$ & $24(32.4)$ & $26(24.5)$ & $14(29.2)$ & 30 (18.5) & $28(37.3)$ & $6(8.6)$ & $10(21.3)$ \\
\hline \multicolumn{10}{|c|}{ Vomiting } \\
\hline No & $318(89.8)$ & $120(95.2)$ & $57(77.0)$ & $96(90.6)$ & $45(93.8)$ & 149 (92.0) & 65 (86.7) & $67(95.7)$ & 37 (78.7) \\
\hline Yes & $36(10.2)$ & $6(4.8)$ & $17(23.0)$ & $10(9.4)$ & $3(6.3)$ & $13(8.0)$ & 10 (13.3) & $3(4.3)$ & $10(21.3)$ \\
\hline \multicolumn{10}{|c|}{ Weakness } \\
\hline No & $260(73.4)$ & 105 (83.3) & 53 (71.6) & 73 (68.9) & $29(60.4)$ & $120(74.1)$ & $51(68.0)$ & $58(82.9)$ & $31(66.0)$ \\
\hline Yes & $94(26.6)$ & 21 (16.7) & $21(28.4)$ & $33(31.1)$ & 19 (39.6) & $42(25.9)$ & $24(32.0)$ & $12(17.1)$ & $16(34.0)$ \\
\hline \multicolumn{10}{|c|}{ Bellyache } \\
\hline No & 282 (79.7) & $116(92.1)$ & $58(78.4)$ & $72(67.9)$ & $36(75.0)$ & $128(79.0)$ & $57(76.0)$ & 60 (85.7) & 37 (78.7) \\
\hline Yes & $72(20.3)$ & $10(7.9)$ & $16(21.6)$ & $34(32.1)$ & $12(25.0)$ & $34(21.0)$ & $18(24.0)$ & $10(14.3)$ & $10(21.3)$ \\
\hline
\end{tabular}

\section{Table 5}

Multivariate analysis between green tobacco sickness and associated factors in the study population. Dom Feliciano Municipality, Rio Grande do Sul State, Brazil $(n=301)$.

\begin{tabular}{lccc}
\hline & OR [Ref.: no] & $\mathbf{9 5 \% C l}$ & p-value \\
\hline Time of sunlight exposure (hours) [Ref.: $\leq 6$ hours] & & & \\
$\quad 7-8$ & 2.26 & $1.159-4.404$ & $\mathbf{0 . 0 2}$ \\
$\quad>8$ & 2.39 & $1.136-5.028$ & $\mathbf{0 . 0 2}$ \\
Current exposure to pesticides [Ref.: no] & 3.64 & $1.433-9.251$ & $\mathbf{0 . 0 1}$ \\
$\quad$ Health status [Ref.: good or very good] & & & \\
$\quad$ Regular & 1.99 & $1.173-3.376$ & $\mathbf{0 . 0 1}$ \\
$\quad$ Poor or very poor & 1.06 & $0.394-2.847$ & 0.91 \\
Wood cultivation [Ref.: no] & 0.60 & $0.366-0.998$ & $\mathbf{0 . 0 5}$ \\
$\quad$ Constant & 0.08 & & 0.00 \\
\hline
\end{tabular}

95\%Cl: 95\% confidence interval; OR: odds ratio; Ref.: reference category.

Notes: model simultaneously adjusted by time of sunlight exposure, current exposure to pesticides, health status and wood cultivation; bold: $p$-value $\leq 0.05$. 


\section{Discussion}

GTS occurrence was observed in the current study in $34.5 \%$ of the population, with a median cotinine equal to $756 \mathrm{ng} / \mathrm{mL}$ and $76 \mathrm{ng} / \mathrm{mL}$ (632ng/mg and $74 \mathrm{ng} / \mathrm{mg}$ of creatinine) in cases and non-cases, respectively. Sunlight exposure, use of pesticides, as well as regular health status were positively associated to GTS, while wood cultivation presented a negative association to the disease occurrence.

Studies conducted in several countries have reported different GTS occurrence frequencies, which varied higher or lower when compared to the ones seen in the present study. A sectional study conducted in Thailand, where only the presence of symptoms was considered to determine GTS, verified a case prevalence of $23 \%$, being $18 \%$ in males and $26 \%$ in females 7 . In India, a study conducted with tobacco farmers and non-tobacco farmers reported a GTS prevalence of $47 \%$ in the farmers who cultivated tobacco ${ }^{6}$. When stratified by sex, a higher disease frequency was seen in females (56\%) than in males (43\%) 6 . Considering the toxicity symptoms and the time of work with tobacco, American studies reported GTS occurrence frequencies from $2 \%$ to $18 \%$, varying due to the year period $3,5,17$. A disease prevalence from up to $10 \%$ and $16 \%$ in males and females, respectively, was identified in a Brazilian study that considered subjects who manifested tobacco toxicity symptoms in up to two days after the tobacco harvest as being GTS cases 8. The observed range of GTS frequencies could be attributed to the different methodologies used by such studies, as well as to the different traits of the tobacco productive processes in the different locations, according to the type of growing tobacco $3,5,6,7,8,17$.

Contrarily to the results found in other studies 6,7,8, a slightly higher GTS prevalence in Dom Feliciano was seen in males (37\%) instead of females (31\%). However, the results seen in the present study are similar to the ones in the other two national studies that measured the cotinine urinary levels 10,18. These results suggest that not using such parameter to define GTS cases may bias the results, as females could have more facility in reporting the symptoms more precisely when compared to males 8 , even with lower exposure 18 .

The cotinine can be determined in different biological matrices (e.g., blood, saliva, and urine) 19. Though the Brazilian Ministry of Health sets cotinine levels as one of the parameters to define GTS cases, many studies do not analyze such nicotine metabolite, only considering the symptoms and the time of exposure to tobacco leaves to determine the disease cases 3,5,6,7,8,17. A cross-sectional study with tobacco farmers in Rio Grande do Sul found no difference in urinary cotinine levels between GTS symptomatic and asymptomatic subjects, suggesting that cotinine is not an indicator of nicotine poisoning ${ }^{20}$. However, is important to consider the cotinine level since the symptoms of GTS are nonspecific ${ }^{3}$ and that this nicotine metabolite is one of the parameters of the case definition of GTS 1. The population of Dom Feliciano presented high cotinine levels (cases $=1,093 \mathrm{ng} / \mathrm{mL}$; noncases $=533 \mathrm{ng} / \mathrm{mL}$ ) when compared to other studies that evaluated such metabolite in urine 10,18. A case-control study conducted in Rio Grande do Sul reported a mean cotinine urinary concentration of $432 \mathrm{ng} / \mathrm{mL}$ and $353 \mathrm{ng} / \mathrm{mL}$ for GTS cases and controls, respectively 10 . Stratifying by smoking, cotinine levels of $742 \mathrm{ng} / \mathrm{mL}$ in cases and $821 \mathrm{ng} / \mathrm{mL}$ in controls smokers, and $255 \mathrm{ng} / \mathrm{mL}$ and $68 \mathrm{ng} / \mathrm{mL}$ for cases and controls non-smokers, respectively 10, were identified. Other Brazilian study conducted in Arapiraca, Alagoas State, identified median cotinine urinary levels of $811 \mathrm{ng} / \mathrm{mL}$ in GTS cases and $1,293 \mathrm{ng} / \mathrm{mL}$ in controls in smokers, while levels of $288 \mathrm{ng} / \mathrm{mL}$ and $156 \mathrm{ng} / \mathrm{mL}$ were detected in cases and controls, respectively, for non-smokers 18 . Considering the significance of the kidney function in the cotinine urinary concentration 19 , the levels of such metabolite were presented as adjusted and non-adjusted by creatinine in the present study. However, the studies do not perform this correction in general, which makes the comparison of the found results impossible.

A sunlight exposure for a period from 7 to 8 hours and longer than 8 hours were positively associated to GTS occurrence, being suggestive of dose-response effect. This result can be explained by the hydrosoluble and liposoluble features of nicotine 3,21, as the dermal absorption of nicotine is facilitated by humidity 18 and is possibly aggravated in hot environments due to higher transpiration. Furthermore, some typical GTS symptoms can be also caused by exhaustion by heat cause by an exaggerated sunlight exposure 4 . Likewise, an acute toxicity by pesticides, substances widely used by tobacco farmers (87\%), has shown strong association to the GTS occurrence. A recent study by the same research group 22, it was verified that the tobacco farmers in Dom Feliciano used insecticides 
(pyrethroids, organophosphates), herbicides (dinitroaniline, isoxazolidinone, substituted glycine), and fungicides (dicarboximide) that can present clinical manifestations similar to the GTS ones 23, which could justify the association found for such environmental contaminant 4 . In such aspect, it is important to highlight the association verified in the bivariate analysis between bean cultivation and GTS. Bean cultivation presents a released use of 134 pesticides from 57 different chemical groups, with pyrethroids, triazoles, and organophosphates being highlighted among such groups 24 , and which muscarinic manifestations (such as colic and vomiting) are similar to the GTS symptoms 25 .

The perception of the health condition of a subject as being regular also presented a positive association to GTS, while the health status reported as being poor or very poor did not present any statistically significant association. Understanding the health perception from physical and subjective dimensions and the capacity for working composes a significant factor to refer the health status 26. Thus, the observed results could be explained by the higher susceptibility of those who present debilitated health, but are able to work, as subjects that perceive their health as poor or very poor could perform the field activities less intensively, being less exposed to the tobacco leaves. Referring to the inverse association verified for wood cultivation, this could result from a smaller farmer's dependence on the tobacco crop due to the production of wood, which would protect the farmer against the harmful effects of the exposure to tobacco leaves. Similar results were seen by Fassa et al. 8 for dairy production in a study conducted in farmers in São Lourenço do Sul, Rio Grande do Sul State. Thus, it is highlighted that WHO-FCTC prescribed a diversification of crops in tobacco-producing areas, aiming a gradual substitution of the smoke cultivation 11.

The memory bias from the data obtainment by a reminding report is a possible limitation in such study. However, the use of cotinine levels to set GTS cases is strongly highlighted, according to a recommendation from the Brazilian Ministry of Health 1, as well as the presentation of such metabolite levels adjusted by creatinine, a significant indicator of kidney function 19 .

\section{Conclusion}

The tobacco-producing farming population in Dom Feliciano Municipality, in the Southern region of Brazil presented high GTS prevalence. The results suggest that the use of urinary cotinine is a significant biological marker to determine GTS cases, influencing in the disease prevalence distribution by sex. The study indicated an association between GTS and sunlight exposure, use of pesticides, health perception, and wood cultivation.

Brazil's position regarding tobacco production and export and the health hazards from the exposure to nicotine, as well as the intensive use of pesticides and other risk factors typical of tobacco cultivation (such as exhaustion and dependence on tobacco industry), evidence the significance of this theme for public health and the urge for implementing measures to prevent the harm caused to such workers, as set in Articles 17 and 18 of WHO-FCTC, which set alternatives for such crop in order to protect the health and the environment against its negative effects. 


\section{Contributors}

E. Campos participated in the statistical analysis, interpretation of data, writing of the manuscript and approval of the final version. V. I.-B. Costa, V. Cunha, T. M. Cavalcante and M. Sarpa contributed in the critical review and approval of the final version. S. R. Alves, A. C. S. Rosa and B. C. Meira collaborated in the laboratory analysis, critical review and approval of the final version. B. R. Geraldino contributed in the interpretation of data, critical review and approval of the final version. S. R. Turci and U. B. Otero participated in the research conception, critical review and approval of the final version.

\section{Additional informations}

ORCID: Élida Campos (0000-0003-1604-8845); Vanessa Indio-do-Brasil da Costa (0000-00020360-143X); Sérgio Rabello Alves (0000-00024181-1163); Ana Cristina Simões Rosa (00000003-0547-1138); Bárbara Rodrigues Geraldino (0000-0002-7061-1574); Beatriz da Cruz Meira (0000-0001-7107-1242); Valéria Cunha (00000003-0944-3337); Tânia Maria Cavalcante (00000003-0866-4672); Silvana Rubano Turci (00000003-0811-9252); Marcia Sarpa (0000-0001-89764653); Ubirani Barros Otero (0000-0003-14642410).

\section{Acknowledgments}

We thank the Pan American Health Organization (PAHO); E. Rangel, MSc.; M. Moreno, PhD.; M. Câmara, PhD.; J. Chrisman, PhD.; P. Vaz, MSc.; P. Bocolinni, PhD.; F. Pinto, MSc.; C. Noronha, Msc.; F. Gomes, PhD.; Mr. E. Franco; Mrs. S. Couto; Mrs. A. Cardoso, Mrs. V. Borges, Mrs. M. Martins, Mrs. E. Ribeiro, Mrs. L. Portal, Mrs. T. Santos; City Hall and Family Health Care Team of Dom Feliciano, State Center of Health Surveillance, Department of Health Actions/Food and Nutrition Policy, and Central Laboratory of Rio Grande do Sul for support in performing the study.

\section{References}

1. Ministério da Saúde. Doença da folha verde do tabaco. http://bvsms.saude.gov.br/bvs/di cas/204_doenca_folha_verde.html (accessed on $27 /$ Oct/2014).

2. Riquinho DL, Hennington EA. Cultivo do tabaco no sul do Brasil: doença da folha verde e outros agravos à saúde. Ciênc Saúde Colet 2014; 19:4797-808.

3. Arcury TA, Vallejos QM, Schulz MR, Feldman SR, Fleischer AB, Verma A, et al. Green tobacco sickness and skin integrity among migrant Latino farmworkers. Am J Ind Med 2008; 51:195-203.

4. Riquinho DL, Hennington EA. Health, environment and working conditions in tobacco cultivation: a review of the literature. Ciênc Saúde Colet 2012; 17:1587-600.

5. Arcury T, Quandt S, Preisser J. Predictors of incidence and prevalence of green tobacco sickness among Latino farmworkers in North Carolina, USA. J Epidemiol Community Health 2001; 55:818-24.

6. Parikh JR, Gokani VN, Doctor PB, Kulkarni PK, Shah AR, Saiyed HN. Acute and chronic health effects due to green tobacco exposure in agricultural workers. Am J Ind Med 2005; 47:494-9.

7. Saleeon T, Siriwong W, Maldonado-Pérez HL, Robson MG. Green tobacco sickness among Thai traditional tobacco farmers, Thailand. Int J Occup Environ Med 2015; 6:169-76.

8. Fassa AG, Faria NMX, Meucci RD, Fiori NS, Miranda VI, Facchini LA. Green tobacco sickness among tobacco farmers in southern Brazil. Am J Ind Med 2014; 57:726-35.

9. Sindicato da Indústria do Tabaco. Brasil é líder mundial em exportação de tabaco. http://sin ditabaco.com.br/sobre-o-setor/exportacoes/ (accessed on 24/Feb/2015).

10. Bartholomay P, Iser BPM, Oliveira PPV, Santos TEHH, Malta DC, Sobel J, et al. Epidemiologic investigation of an occupational illness of tobacco harvesters in southern Brazil, a worldwide leader in tobacco production. Occup Environ Med 2012; 69:514-8.

11. Instituto Nacional de Câncer José Alencar Gomes da Silva; Organização Mundial da Saúde. Convenção-quadro para o controle do tabaco. Rio de Janeiro: Instituto Nacional de Câncer José Alencar Gomes da Silva; 2011.

12. Onde mais se produz tabaco no Sul Brasil? Portal do Tabaco 2016; 25 jan. http://portal dotabaco.com.br/onde-mais-se-produz-taba co-no-sul-do-brasil/.

13. Segall-Corrêa AM, Escamilla RP, Maranha LK, Sampaio MFA. (In)segurança alimentar no Brasil: validação de metodologia para acompanhamento e avaliação. Relatório técnico. Campinas: Departamento de Medicina Preventiva e Social, Faculdade de Ciências Médicas, Universidade Estadual de Campinas; 2003. 
14. Bernadt MW, Mumford J, Taylor C, Smith B, Murray RM. Comparison of questionnaire and laboratory tests in the detection of excessive drinking and alcoholism. Lancet 1982; 1:3258.

15. Dhar P. Measuring tobacco smoke exposure: quantifying nicotine/cotinine concentration in biological samples by colorimetry, chromatography and immunoassay methods. J Pharm Biomed Anal 2004; 35:155-68.

16. Junge W, Wilke B, Halabi A, Klein G. Determination of reference intervals for serum creatinine, creatinine excretion and creatinine clearance with an enzymatic and a modified Jaffé method. Clin Chim Acta 2004; 344:137-48.

17. Arcury TA, Quandt SA, Preisser JS, Bernert JT, Norton D, Wang J. High levels of transdermal nicotine exposure produce green tobacco sickness in Latino farmworkers. Nicotine Tob Res 2003; 5:315-21.

18. Oliveira PPV, Sihler CB, Moura L, Malta DC, Torres MCA, Lima SMCP, et al. First reported outbreak of green tobacco sickness in Brazil. Cad Saúde Pública 2010; 26:2263-9.

19. Malafatti L, Martins I. Aspectos analíticos da determinação de cotinina em matrizes biológicas. Rev Bras Toxicol 2009; 22:9-20.

20. Fassa AG, Meucci RD, Fiori NS, Carrett MLV, Faria NMX. Urinary cotinine in tobacco farmers in Southern Brazil. Rev Saúde Pública 2018; 52:70.
21. Arcury TA, Quandt SA. Health and social impacts of tobacco production. J Agromedicine 2006; 11:71-81.

22. Campos E, Silva VSP, Mello MSC, Otero UB. Exposure to pesticides and mental disorders in a rural population of Southern Brazil. Neurotoxicology 2016; 56:7-16.

23. Costa LG. Toxic effects of pesticides. In: Klaassen $\mathrm{CD}$, Watkins III JB, editors. Casarett \& Doull's essentials of toxicology. 2nd Ed. New York: McGraw-Hill; 2010. p. 309-22.

24. Ministério da Agricultura, Pecuária e Abastecimento. AGROFIT - Sistema de Agrotóxicos Fitossanitários. http://agrofit.agricultura.gov. br/agrofit_cons/principal_agrofit_cons (accessed on 20/Nov/2017).

25. King AM, Aaron CK. Organophosphate and carbamate poisoning. Emerg Med Clin North Am 2015; 33:133-51.

26. Riquinho DL, Gerhardt TE. A transitoriedade nos estados de saúde e doença: construção do cotidiano individual e coletivo em uma comunidade rural. Trab Educ Saúde 2010; 8:419-37. 


\section{Resumo}

O estudo teve como objetivo avaliar a ocorrência de doença da folha verde (DFV) e fatores associados entre fumicultores familiares no Município de Dom Feliciano, Estado do Rio Grande do Sul, Brasil. Foi realizado um estudo transversal sobre DFV em 354 pequenos produtores de tabaco, entre outubro de 2011 e março de 2012. Foi medida a concentração urinária da cotinina, um biomarcador da exposição à nicotina, durante a temporada de colheita do tabaco. Os casos de DFV foram definidos como indivíduos com níveis urinários de cotinina $\geq 50 \mathrm{ng} / \mathrm{mL}$, que tiveram contato com folhas de tabaco em até 48 horas antes da coleta da amostra sanguínea e que relatavam pelo menos um sintoma da doença. Foi realizada uma análise logística não condicional para avaliar a associação entre DFV e as características da população. Foram identificados um total de 122 (34,5\%) casos da doença, entre os quais 39\% eram fumantes e $61 \%$ eram do sexo masculino. As concentrações urinárias medianas de cotinina foram 75, 6ng/ $m L$ (74,1ng/mg de creatinina) para não-casos $e$ $755,8 \mathrm{ng} / \mathrm{mL}(632,1 \mathrm{ng} / \mathrm{mg}$ de creatinina) para os casos (valor de $p \leq 0,01$ ). A análise multivariada mostrou uma associação positiva entre DFV e tempo de exposição à luz solar, exposição a pesticidas e pior estado de saúde geral, e uma associação inversa com cultivo de lenha. $O$ estudo identificou alta prevalência de DFV e sugere o uso da cotinina como biomarcador significativo para identificar os casos de DFV, influenciando a distribuição por sexo. Uma vez que a fumicultura envolve danos à saúde, é importante implementar medidas para prevenir os impactos para os fumicultores, de acordo com os artigos 17 e 18 da Convenção-Quadro para o Controle do Tabaco da Organização Mundial da Saúde.

Cotinina; Nicotina; Indústria do Tabaco

\section{Resumen}

Este estudio visó evaluar la ocurrencia de la enfermedad del tabaco verde (GTS por sus siglas en inglés) y sus factores asociados en pequeños agricultores de tabaco, que residen en Dom Feliciano, Rio Grande do Sul, Brasil. Se realizó un estudio transversal, evaluando la enfermedad del tabaco verde, en 354 pequeños agricultores de tabaco, entre octubre de 2011 y marzo 2012. La concentración urinaria de cotinina, un biomarcador de la exposición a la nicotina, se determinó durante el periodo de cosecha del tabaco. Los individuos que presentan niveles de cotinina urinarios $\geq 50 \mathrm{ng} / \mathrm{mL}$, que tuvieron contacto con hojas de tabaco hasta 48 horas antes de la recogida de la muestra, e informaron de al menos un sintoma de la enfermedad, fueron considerados casos. Se realizó un análisis logístico no condicional para evaluar la asociación entre GTS y las características de la población. Se identificaron un total de $122(34,5 \%)$ casos, siendo un $39 \%$ de ellos fumadores y un $61 \%$ hombres. Las concentraciones medias de cotinina urinaria fueron $75,6 n g / m L ~(74,1 n g / m g$ de creatinina) para los no casos y 755, 8ng/mL (632, $1 \mathrm{ng} / \mathrm{mg}$ de creatinina) para los casos (valor de $p \leq 0,01$ ). El análisis multivariado mostró una asociación positiva entre el GTS y las horas de exposición a la luz solar, exposición a los pesticidas, un estatus peor de salud, y la asociación inversa con la cultura maderera. Este estudio presentó una alta prevalencia de GTS y sugiere que el uso de la cotinina urinaria es un biomarcador significativo para identificar casos de GTS, influenciando en la distribución por sexo. Debido a que la producción de tabaco implica perjuicios para la salud, es importante implementar medidas para prevenirlos en los agricultores del tabaco, como está estipulado en los artículos $17 y$ 18 del Convenio Marco para el Control del Tabaco de la Organización Mundial de la Salud.

Cotinina; Nicotina; Industria del Tabaco
Submitted on 29/Jun/2019

Final version resubmitted on 30/Nov/2019

Approved on 27/Jan/2020 